\title{
Opinion piece: On syncretism as image for global union and on the spectre of difference. comments on the abstract of session 10 of the conference of the international society for the sociology of religion
}

\begin{abstract}
The concepts of â€œsyncretismâ€ and of â€œdifferenceâ€ have become increasingly important in the past few years, as a long period after World War II, in which mass migrations of labourers from â€œthe southâ€, both in Europe and in North America, and some migration of academically qualified people, have profoundly changed societies and cultures here. Some cultural elements of these immigrants have been enthusiastically received as enrichment of local culture. A spirit of â€œmulticulturalismâ€ emerged. In Brazil this played out in the attitude of white and middle class milieus towards the African and Amerindian parts of the population and their distinct cultures. Their integration towards a comprehensive and thus genuine Brazilian-ness was sought. The Afro-Brazilian syncretistic religions were perceived enthusiastically as symbols and manifestations of such inspiring mergers by authors in Brazil and abroad, especially by Roger Bastide. Syncretism thus became an ideal of cultural and political significance. Over the past decade the mood has swung in Europe and in North America, with tendencies towards â€œde-limitationâ€ and emphasis on difference becoming prevalent. On this background the announcement of the thematic session of the conference of the International Society for the Sociology of Religion

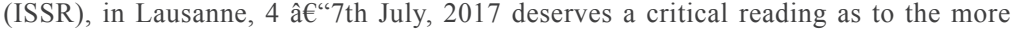
concise meaning of the concept of â€œsyncretismâ€ and its relation to issues of structure, identity and difference.
\end{abstract}

Keywords: syncretism, session, conference, ethnic, cultural, indeed, religious, theoretical, celebration, universalism, métissage
Volume 2 Issue 6 - 2018

\author{
Ullrich Kleinhempel \\ Department of Contemporary Spiritual Movements, University \\ of Bavaria, Germany
}

\begin{abstract}
Correspondence: Ullrich Kleinhempel, Department of Contemporary Spiritual Movements, University of Bavaria, Heilstaetten Stzr. 150 90768, Germany, Tel +49-151-19697960, Email u.kleinhampel@gmail.com
\end{abstract}

Received: December 29, 2017 | Published: November 26, 2018

\section{Opinion}

Distinguished Interpreters of the relationship between religion and society, like Roger Bastide and others, viewed countries like Brazil as the prototype of a brave new world, This would largely be due to the interpenetration of the ethnic, cultural and, indeed, religious strains that entered into the composition of such countries. In France, too, a main line of thought looked with an optimism verging into enthusiasm, at the assimilating capacity of the French civilization. Yet, in both Brazil and France like in several other countries, antisyncretistic and fundamentalist currents seem to have become only stronger in the first two decades of the $21^{\text {st }}$ century. This has led to a situation that was certainly unexpected by authors such as Franz Boas and Roger Bastide, writing by the middle of the 20th century, on the interpenetration of civilizations in the Muslim word and in Brazil. Taking also into account valuable earlier contributions, this session aims both at a description of concrete issues and at an essay or essays of theoretical explanation of such trends. The question looms large whether religions will ever be entirely able to renounce their claims to exclusiveness and, hence, to fundamentalism and intolerance, even if the latter does not take an overtly violent shape. This query, in spite of many statements of acts of good will by religious leaders, concerns, first and foremost, monotheistic and revealed forms of religion, in which the door of syncretism tends to be absent, or very narrow. ${ }^{1}$

${ }^{1}$ International Society for the Sociology of Religion (ISSR) conference, Lausanne, 4- $7^{\text {th }}$ July, 2017. List of sessions] Thematic Session STS \#10:
This text is rich in emotion and alludes to a spirit of celebration of universalism and "métissage" on the basis of an imagined universal civilisation, such as French or Brazilian civilisations are hailed here to have been. It alludes to a spirit of embracing of the "Other" which formed an emancipatory ideal throughout the $20^{\text {th }}$ century, in spite of murderous opposition in some decades. Associated areimages of syncretism and with an "assimilating capacity". They are opposed to monotheistic religions which are allegedly anti-syncretistic.

This statement confounds two spheres, of religion and of culture. It alludes to Jan Assmann's thesis of the "Mosaic distinction" which he saw as the invention of difference ("Monotheistische Unterscheidung") and exclusive claims to truth as of monotheism. Assmann construes an opposition between "natural religion" of cosmo-theism, in which culture and religion are coextensive. With the event of "revelation" and with the codification of revealed truths, such (chiefly) monotheistic religions became detached from culture, and able to migrate to the different cultures to establish themselves there. The distinction between "nature" (or the "natural" state of affairs and values in any culture and revelation became a constituent difference. Assmann states that this is associated with their power for ethical guidance, with their trait of interiorization and with their clear

Conveners Roberto M.C. Motta, Claude Ravelet, Léa Freitas Perez. Title: Religious and Cultural Syncretism, Interpenetration, Fundamentalism, Intolerance, and Conflict in Brazil, France and Elsewhere: Comparative Views". 
distinction between good and evil which gives the power of ethical guidance to societies. ${ }^{2}$ Assmann calls this an "antagonistic power" vis-à-vis of cultures and societies-or of the "natural" state of affairs.

On this background the appeal to the French and Brazilian cultures as models of integration requires second looks. As to France the claim of the French Revolution to represent a "natural state", with the French language as unifying bond and medium, came with ruthless measures of elimination of cultural "difference" in France: minority languages were rigorously suppressed and deprived of means of cultural reproduction and expression by their exclusion from schools. This process of coerced assimilation was likewise practised in the colonies. The integration of the "other" came at the price of denial of alterity. In the end, the elimination of alterity serves to make the dominant state of affairs and of culture natural. In Brazil the process of amalgamation of very different cultures, of the Portuguese, the African of Bantu and West African origins and of the Amerindians was-and continues to be-a complex process of fusion which brought about Brazilian culture and identity, shared by almost all. This has been described and appreciated as the foundation of Brazilian identity by the sociologist and cultural anthropologist Gilberto Freyre ${ }^{3}$ and remains influential ever since. This process of amalgamation can be described as cultural "syncretism". However this implies an understanding of syncretism as a structured systemic process, as described by Ulrich Berner. ${ }^{4}$

In such processes there is usually a dominant receiving system, which receives specific elements of a different culture or religion on its own terms. This process can also include the addition of elements which have so far lacked in the receiving system. The inclusion can

${ }^{2}$ Assmann, Jan, Die Mosaische Unterscheidung oder der Preis des Monotheismus, Munich, 2003: Hanser Vlg. [English translation: The Mosaic Distinction and the Price of Monotheism, Stanford: 2010: Stanford Univ. pr.]

${ }^{3}$ Freyre, Gilberto, Casa grande \& senzala: formacao da familia brasileira sob o regime de economia patriarcal, 2 vols., Rio de Janeiro, 1933: Maia e Schmidt

Ltda.

${ }^{4}$ Berner, Ulrich. Untersuchungen zur Verwendung des Synkretismus-Begriffs. (Publications of the special research department of Orientalistics at the GeorgAugust-University of Göttingen, vol. 2), Wiesbaden, 1982: Otto Harrassowitz lead to a modification of the receiving system when the received elements unfold their own inherent systemic dynamics, especially if their inclusion has been merely superficial. ${ }^{5}$ Freyre describes how in some cases, especially as relates to maternal elements, the African elements became dominant in Brazilian culture, whereas the patriarchal elements remained largely Portuguese. In reflecting on this mixed identity the Afro-Brazilian religions became heralded as mirrors of this syncretism. What remains overlooked is that they are very structured and implicitly "dogmatic", as encoded in ritual, hierarchy and imagery. Their "syncretistic stage" is largely completed. ${ }^{6}$ The dynamics of present Brazilian culture is marked by the dynamic growth of Pentecostalism. It reinstates the "Mosaic distinction" by criticising Brazilian traditional values and mores, calling for change. As such they are criticised as being "alien". It seems however that their adherents experience a change of their life which they cherish and which contributes to the further attractiveness of Pentecostalism, which is itself quite syncretistic as to its ritual expression and some concepts. Instead of bemoaning the rise of such vigorous religious "alternatives" the "West" might question its own claims to representing "nature" and a "natural state" of culture and affairs. It might be a challenge to look into the dynamics of "difference" which are unfolding themselves again, especially at the margins of "Western" culture.

\section{Acknowledgments}

None.

\section{Conflicts of interest}

The author declares that there is no conflicts of interest.

${ }^{5}$ Hollenweger, Walter. Pentecostalism. Origins and Developments Worldwide. Peabody, 1997: Hendrickson Publ.

${ }^{6}$ Kleinhempel, Ullrich R., Spiritual Experience in Orthodoxy and the Pentecostal Concept of the Works of the Holy Spirit. A Comparative Study [paper in partial fulfilment of requirements towards a doctorate at the UNESCO Chair of Intercultural and Interreligious Studies. 